\title{
Multicultural and Character Education as the Model of Mental Revolution Movement to Prevent Santri Radicalism
}

\author{
Haris Supratno \\ Universitas Negeri Surabaya \\ Surabaya, Indonesia \\ harissupratno@unesa.ac.id
}

\author{
Resdianto Permata Raharjo \\ Universitas Negeri Surabaya \\ Surabaya, Indonesia \\ rezdyraharjo@gmail.com
}

\begin{abstract}
The goal of this research was to find the model of character and multicultural education as the model of mental revolution movement to tackle santri radicalism in Pesantren in East Java. This research used a qualitative method. The data sources were taken from the informant, including teachers, Pesantren guardians, administrators, and santri. Technique for collecting the data used observation, interview, recording, and taking notes. The data was analyzed by the descriptive analysis and content analysis. Based on the finding of this research, it could be concluded that character and multicultural education model in Pesantren in East Java used a role model form, and it had been implemented in the daily life and also became part of Pesantren culture. In addition, character and multicultural education as the mental revolution movement of santri could become media for tackling santri radicalism.
\end{abstract}

Key Words: character education, multicultural, radicalism, santri, and pesantren.

\section{INTRODUCTION}

Pesantren today have already changed. But it still able to maintain its characteristic, namely as traditional educational institutions that are able to have a robust culture endurance and flexible education system so that they are able to adjust with any changes and development of the era [1]. Pesantren is one of the general models of community-based education which is established by Muslim community to educate students in understanding and practising Islam [2]. Pesantren have an important role in the construction of the moral, empowerment and community development, especially for the young generation, because one characteristic of pesantren is implementing education based on the religion of Islam. Pesantren can also empower people, especially the surrounding community empowerment either social, culture, religion or economy field [3][4][5].

Based on the research done in 2015 and 2016, it is found that there are various phenomenon in Pesantren that is interesting, namely model of character and multicultural education [6][7]. This character and multicultural education is a very strategic process in the intellectual life of the nation to prepare qualified human resources and it must be done professionally [8]. Character and multicultural education in Pesantren are very interesting and are able to form a strong and independent character of santri which can be used as media preventions of radicalism behavior. The problem of radicalism in Indonesia and abroad often associated with Islam and terrorists, because many perpetrators of radicalism were done by the Muslim people. The impression is gained after the disclosures by the perpetrators of the Bali bomb, turns to the Islam and pesantren alumni so that the perpetrators of radicalism and terrorists are always linked with Islam and Pesantren. It is strengthened by the bombings in United States on 11 November 2004, who the perpetrators are also Muslim so that in Europe and America is known Islamphobia.

As a preliminary study to prevent the radicalism of both santri behavior and the way of thinking, the use of media character and multicultural education is good to be applied. Character education is an integral part of which could not be separated with education activities. According to some communities, education must be able to bring benefit to the community, such as giving life skill and soft skill for the community who believes education as the ability owned by learners to face the challenge of living in the community. Education must cover the aspects of knowledge, attitudes and skills. The attitude is one of important aspect to establish the attitude, ethics, moral, and outstanding traits that are more currently known as character education or mental revolution. The development of the characters is an important role for young generation that must be started since the early age of education, either formal education or informal education, including education in Pesantren [9][10].

Education as the process of empowerment must contain the education value or characters. Education value or character is an effort to help learners to know, to realize the importance of education and to perceive values that can be used as a guide or model of the attitudes and behavior of human being as an individual and as a member of the community. Character education and personality are the integral part of the cultural education. Character and personality education for learners, can be obtained through family and school education. Character education since the beginning of its emergence plays an important role in the process of empowering character education of children because 
it will form an individu who is sincere and more concerned by the environment [9][10].

Character education is very important to be applied in Indonesia which is currently experiencing a number of events that lead to disintegration of the nation and decadence of the moral ethics in society, even some elites of the nation that resulted losing its personality as religious, civilized, and dignified nation in Indonesia [11]. Meanwhile, the traditions of education seem immature to implement character education. Character education can be made as a capital to form the character of young generation that are deeply rooted in the cultural and religious values [9][10][12][13].

Character education is able to improve academic achievement. Religious behavior as the obedience of worship has some effects on patience, politeness, honesty, diligence, dauntless, independence and responsibility. The attitudes and behavior of honest influence the commitment of a man. The attitude to appreciate the achievements, acknowledge and appreciate the success of others affect the person creativity. The attitudes and behavior of patience, politeness and respect to other people of different faith affect the characters of love, peace and social concerns [14]. The scope of character education is taken from religion, Pancasila, culture and the purpose of the national education that includes: religious, honest, tolerant, discipline, hardworking, creative, independent, democratic, curiosity, having nationalism spirit, loving the homeland, high-minded, friendly/communicative, calm, have a reading habit, concerned for the environment and social, and responsible [15].

Pesantren is called as a multicultural society because santri consists of various and different tribes and cultures. But they are respect each other, appreciate and tolerant. Though different people and culture, but they can live side by side together. But these days, in Indonesia, much of the violence such as radicalists, fundamentalists, and terrorists use Islam as their name [16].

Multicultural Society can be categorized into three (1) community phenomenon that indicates cultural diversity based on the characteristics of subculture society that is still in a scope of culture, (2) diversity based on the critical ideas that developed in a society, and (3) cultural diversity based on the awareness of different principles of beliefs and practices in a society that more complex and pluralistic. Pluralism is one of the characteristics of the Indonesian people to be cultivated about the values of togetherness, tolerant, respect and acknowledge their existence in order to adapt to the various differences to avoid conflict [17][18].

The character and multicultural education in Pesantren is a model of mental revolution movement that can be used as media for tackling radicalism. Radicalism phenomenon lately developed again in various countries such as in Indonesia, United States, Thailand, Burma as well as in the Middle East. Radicalism is often associated with Islam, conservatives or fundamentalists, oppositions, political ideology and terrorists, so that in the West, it emerges Islampobia [19][20][21]. In the view of Western world, Islamic fundamentalist, fanatics, and terrorists are stronger after the event of World Trade Center in New York on 11 September
2001 [19]. Radicalism appears due to certain groups who feel disappointed or dissatisfied against injustice, the gap and oppression experienced by certain groups [22][23]. Radicalism is understood as the doctrine that will make some revolutionary, comprehensive, and fundamental changes without regard legislation, political, social and religious. Radicalism can include thought or the ideology and action both in politics and religion [24].

\section{RESEARCH METHOD}

This research used a qualitative method because the data were taken in the form of natural data, more emphasizing process. The location of the research is Pesantren in East Java. The data sources of this research were obtained from some informants, namely Pesantren caregivers, teachers, administrators, and santri. The data of this research was the model of character and multicultural education in Pesantren in East Java as mental revolution movement model to prevent santri radicalism. The techniques of data collection were in the form of observation, interview, recording and taking notes. The data analysis technique used was descriptive analysis. While the data analysis procedures were using the steps: redundancy, classification, coding, interpretation and conclusion.

\section{FINDING AND DISCUSSION}

\section{A. Education Characters Model in Pesantren}

Character education is one of a very precise media to educate and produce santri who have faith, piety, good manner, and strong character. By the character education, santri will have good attitude, behavior, utterance, manner and moral, and also has extensive knowledge. Large and modern Pesantren in general, beside holding informal education, they also have implemented a formal education from the level of basic education until Islamic Colleges as well as Public Universities. The educational model is used to integrate religious and general curriculum. The aim is to give their knowledge of religion and public sciences to the santri in order to become candidates for future leaders who have faith, piety, and honorable supremacy.

Character education model in Pesantren generally appears in the attitudes and behavior, and the language used in daily life, either in the formal education, informal education, or in the activities outside education. Character education in Pesantren is not in the form of lessons or courses but in the form of a sample/model or uswatun khasanah which has been implemented in the form of daily life activities, either in the activities of formal education, informal education or activities outside education. As the attitude model of santri education in formal education, when educators, teachers and students enter the classroom, they always say salam. At the time of the educators began to carry out the learning process always starts or opened with Assalamualaikum Warahmatullahhi Wabarakatuh. Also at the end of learning process, they also ended with the word Assalamualaikum Warahmatullahhi Wabarakatuh. The behavior of religious educators, teachers, 
and kiai is cultivated in everyday life both in the formal and informal activities.

The santri character education also appear on when they meet with teachers, lecturers, kiai and caregivers of Pesantren, santri will shake hands by bowing as a mark of respect and kissing their hand. Such behavior shows characters and politeness and the form of tribute to teachers, lecturers, kiai, and the caregivers are very high. Very much different from the attitudes and behavior of the students in the public education world. In the world of public education, students tend to neglect their teachers or even pretending not to see them. It shows one of the character education indicators in the public formal education has not been successful yet. There are even students who do violence to their teacher or lecturer even until kill them.

Character education model in the field of religious aspects can also be seen when five time prayers. At a time when there was azan (call for praying), the santri are immediately rushing to take ablution and perform prayers together. The discipline of santri is embedded by strong attitudes. At night, santri also have been accustomed to wake up to do tahajud prayers and shubuh prayer in the morning together. Discipline attitude of santri to wake up at night and do tahajud prayer and shubuh prayer in the morning has been embedded and has become daily routine activities so that those activities have become a feature of life in Pesantren.

Character education model in the following formal and informal learning, has also been embedded in santri's good attitude and behavior and has become a routine activity or culture of Pesantren, such as wake up in the tahajud prayer and wake up in the morning to do shubuh prayer, study the classical books after the shubuh prayer, breakfast, follow the activities of formal education from 07.00 a.m. until 01.00 p.m., even in college up to 04.00 p.m., then breaking time, ashar prayer, maghrib prayer, dinner, recite the classical book, isya' prayer, and study. The cycle has become santri routine activities and become culture of Pesantren in general.

Characters education model in simple life, appear on the behavior of santri, teachers, Kyai and caregivers. They live in a simple good way of dressing and polite behavior. For example, generally santri dressed in simple cutting, model and quality, cheap, not striking colors, as it covers the nakedness and sacred. Santri from men always use peci, outside formal education activities, they generally wear sarong and slippers.

Various routine activities of santri have formed stronger characters, such as discipline, polite, and great respect for the teachers, lecturers, Kyai and caregivers. These activities as a model of mental revolution movement can be used as media behavior for preventing santri radicalism. Their mind and heart of santri every day have been accustomed to do this routine cycle both in formal and informal activities. They live in very tight activity schedule, do good participation of formal education and informal education activities so that it does not allow them or only has very small possibility for becoming prosecutor to perform the behavior of radicalism, both in the thought and in the form of deeds. To prepare the qualified and independent santri in Pesantren as well as to the prevention of understanding radicalism since early stage of learning, one of the solutions is done through character and multicultural education, both through formal education and informal education. The character and multicultural education is an integral part of the education and culture which has very important role [10][11].

\section{B. Multicultural Education Model as a Mental Revolution Movement}

The general model of multicultural education in Pesantren in Indonesia also in the form of model that has been implemented in the daily life of santri, both in informal and formal activities. Santri generally comes from the various different areas of social background, culture, language, nation, race and character. But santri never differentiate the origin of, culture, tribe, language, culture and its social status. They can live together and sleep together in one room, respect and appreciate each other, and recognize the right of existence of each. Pesantren is a multicultural society because santri consists of inconvenient people and cultures. But they respect, appreciate and tolerant each other. Though different people and cultures, but they can live side by side, respect and tolerance each other [16].

The model of multicultural education in Pesantren in East Java generally appears on the activities and their daily life. Even though they are from different tribes, different languages and different background of social status, they never questioned about those differences. They can live together by respecting and tolerating each other. They use the same language for their daily communication, they are Bahasa Indonesia, English or Arabic. They are not allowed to form a bond based on ethnicity or regional hometown because it will remove or lose the multicultural feeling which can lead to radical thought and behavior.

The multicultural education model in Pesantren in East Java appeared on the services of the caregiver who always see equally to every santri. It did not differentiate between social status, language, race and culture. All of santri served and treated in a similar place to stay in the room, the same quality of bed used to sleep, the water to drink, the same food and dishes, similar place for worship and gaining education [6]. They were united as santri in a certain Pesantren. The similar pattern of services, including food provided, services as well as the existing facilities that could be used by anyone. They had been accustomed to do such process of learning habit using the same facilities, reciting together, and doing five time prayers together. All of the activities they did could add emotional embedding of santri. They could live together by prioritizing respect, appreciate and tolerant each other.

Multicultural education that occured in Pesantren in East Java used the model of multicultural education in the form of role model/example and behavior implemented in daily life, that was a model of mental revolution movement of santri. The character and multicultural education model had been applied and implemented in the life of Pesantren and had become the culture of Pesantren, long before our government launched the education by the concept of character, until now, it was still in 
the level of concept and had not been implemented yet in the real world of education [9].

\section{CONCLUSION}

Based on explanation above, it can be concluded that the model of character and multicultural education in Pesantren which is applied in the form of a role model/sample or uswatun khasanah in the daily life has become a culture of Pesantren, both in informal and formal activities. Character education model that has been implemented as religious culture, they are tahajud prayer, five time prayers, recite classical book, spread the greeting to anyone, humble and respect for the teachers, Kyai, and caregivers, doing polite behavior, study diligently and living modestly.

The character and multicultural education model in Pesantren is a santri's mental revolution movement model that can become media for preventing radicalism santri in Pesantren, either in the form of thought, ideology, or action.

\section{REFERENCE}

[1] N. Seha, Fungsi Teater Rakyat Ubrug bagi [1] Nasir, Ridlwan. Tipologi Format Pendidikan Ideal. Yogyakarta: Pustaka Belajar, 2005.

[2] M. Toriquddin, "Pemberdayaan Ekonomi di Pesantren Berbasis Syariah,” J. Syariah dan Huk., vol. 3, no. 1, pp. 24-35, 2011.

[3] K. Sumardi, "Potret Pendidikan Karakter Pondok Pesantren Salafiah,” J. Pendidik. Karakter, no. 3, 2012.

[4] D. A. J. Hidayat, "Pemberdayaan Penyesuaian Diri Santri di Pondok Pesantren Tradisional dan Modern,” J. Talent. Psikol., vol. 1, no. 2, pp. 106-126, 2012.

[5] Sholeh, "Persiapan Indonesia dalam Menghadapi AFC (asean economic community)," Ejounal Ilmu Hub. Int., vol. 1, no. 2, pp. 509-522, 2015.

[6] H. Supratno, H. Subandiyah, D. R. Prehanto, and Aris Dwiyanti, Pendidikan Kesehatan Lingkungan Berbasisi Karakter Pondok Pesantren di Jombang. Surabaya: Unesa University Press, 2016.

[7] A. R. Anjana, Melodi Terakhir Sang Muazin Subuh. Banten: Shuhuf Media Insani, 2011
[8] Fatkuroji, "Kesiapan Pendidik dan Tenaga Kependidikan dalam Menyosong Masyarakat Ekonomi ASEAN,” J. Idorah, vol. 1, pp. 101114, 2014.

[9] F. Mu'in, Pendidikan Karakter, Konstruksi Teoritik \& Praktik. Jakarta: Ar Ruzz Media, 2011.

[10] H. A. . Tilaar, Pendidikan untuk Masyarakat Indonesia Baru. Jakarta: Grasindo, 2002.

[11] W. Chrisiana, "Upaya Penerapan Pendidikan Karakter Bagi Mahasiswa (Studi Kasus di Jurusan Teknik Industri Uk Petra),” J. Tek. Ind., vol. 7, no. 1, pp. 83-90, 2005.

[12] R. Afandi, "Integrasi Pendidikan Karakter dalam Pembelajaran IPS di Sekolah Dasar," Pedagogia, vol. 1, no. 1, pp. 85-98, 2011.

[13] N. A. Putri, "Penanaman Nilai-Nilai Pendidikan Karakter Melalui Mata Pelajaran Sosiologi," J. Komunitas, vol. 3, no. 2, 2011.

[14] Sucipto, "Model Pendidikan Karakter di SMA Negeri 1 Sidoarjo," Interaksi, vol. 1, no. 1, pp. 1-7, 2013.

[15] Zulnuraini, "Pendidikan Karakter: Konsep, Implementasi dan Pengembangannya di Sekolah Dasar di Kota Palu," J. Diknas, vol. 1, no. 1, pp. 1-10, 2012.

[16] E. Muliadi, "Urgensi Pembelajaran Pendidikan Agama Islam Berbasis Multikultural di Sekolah,” J. Pendidik. Islam, vol. 1, no. 1, pp. 55-68, 2012.

[17] A. Taufik, "Multicultural Literature: The Identity Construction in Indonesian novels".," Humaniora, vol. 26, no. 1, pp. 22-31, 2014.

[18] I. Arifudin, "Urgensi Implementasi Pendidikan Multikultural di Sekolah,” J. Pemikir. Altern. Pendidik., vol. 12, no. 2, pp. 1-9, 2007.

[19] K. Yusof, I. Herman, and B. M. Nasir, "Islamic Radicalism in Malaysia: an overview," Procedia Soc. Behav. Sci., vol. 5, pp. 2119-2125, 2010.

[20] M. Lauriola, R. Foschi, and L. Marchegiani, "Integrating values and cognitive style in model right-wing radicalism," Pers. Individ. Dif., pp. $147-153,2015$.

[21] D. S. Kim, "The rice of European right radicalism: The case of Jobbik," Communist Post-Communist Stud., pp. 345-357, 2016.

[22] A. Soliman, T. Bellaj, and M. Khelifa, "An integrative psychologigal model for radicalism: Evidence from structural equation modeling," Personal. Individ. Differ., pp. 127-133, 2016.

[23] O. Fedotova, "Radicalism and Terrorism Problems in a Scientific Discourse of Rucian Social Sciences," Procedia Soc. Behav. Sci., vol. 5, pp. 334-343, 2010.

[24] Z. Sesmiarni, "Membendung Radikalisme Dalam Dunia Pendidikan Melalui Pendekatan Brain Base Leraning," Kalam, vol. 9, no. 2, pp. 233-252. 